$\xi=-1$

\title{
Does Securitization for Government Staff Personal Loan Perform?
}

\author{
Mohammed Hariri bin Bakri ${ }^{1}$, Nurayati Dabas ${ }^{2}$, Shafinar Ismail $^{3}$, Baharom Abdul Hamid ${ }^{4}$ \\ ${ }^{1,2}$ Faculty of Technology Management and Technopreneurship, Universiti Teknikal Malaysia Melaka, Hang Tuah Jaya, 76100 Melaka, \\ Malaysia \\ ${ }^{3}$ Faculty of Business Management, Kampus Bandaraya, Universiti Teknologi MARA, 110 off Jalan Hang Tuah,75300 Melaka \\ ${ }^{4}$ International Centre for Education in Islamic Finance (INCEIF ) 59100 Kuala Lumpur, Malaysia \\ *Corresponding author E-mail: hariri@utem.edu.my
}

\begin{abstract}
Malaysian firms have been reported to involve in Asset-Backed Securities since 1986s where Cagamas is a pioneer. The objective of this study to determine the primary market spread and analyze on firm financial performance. The methodology for this paper using regression analysis for the study period 2007-2012. They are three determinants that contribute and statistically significant for this research paper. The measurement of financial performance does not have any impact during subprime mortgage crisis. The firm results shows increasing profitability, reducing debt, stronger company value and shareholders earning better dividend.
\end{abstract}

Keywords: Primary Market Spread; Financial Performance; Profitability Capacity; Dividend Payments A.

\section{Introduction}

Asset-Backed Securities (ABS) was commenced by the USA administration for lodging loan funding plan back in the 1970's and pursued by many securities including mortgage and credit card. After 1980, it was converted into a financing tool and subsequently, it has been extensively extended to all parts of the globe. In the USA, Europe and Asia-Pacific, ABS is growing tremendously and has attracted many fixed income investors to explore in this market for a variety of asset allocation (1). Even though its techniques are more of a complex and complicated financial instrument, it foresees that ABS has an ability to transfer risk with little loss of revenue by a separation of good financial asset for a company. Securitization by finding procedure is the course where uniform but illiquid asset's pooling and packaging process is performed with security interest based on incoming cash flows and sold to third party investors. Since October 2012, ABS has represented alternative long-term funding of auto loans, lease, credit card receivables and commercial mortgages.

The Securities Commission (SC) in 2001 provided obligatory rules securitization of asset and released its rules on the Offering of ABS. On the 10th of April 2001, regarding its possible important involvement to the debt market of Malaysia, it had provided a contribution for insuring Collateralized Bond Obligation (CBO) with the help of Prisma Assets Berhad (2001) which was supported through Ringgit-denominated bonds' pool. An additional CBO deal was supported by Collateralized Loan Obligation (CLO) and by corporate bonds supported by recovering business loans pursuit in the same year. Till December 2012, an anticipated 101 planned dealings have been accepted underneath the Securities Commissions (SC) rules on private debt securities, ABS and supplementary planned merchandises, all of which encompassed an array of asset classes. In a related development in Malaysia, sukuk grew to over US148bil (RM473.7billion) as at June 2013 from US1.5 billion (RM4.8billion) in 2001. The Malaysian sukuk comprises $60.4 \%$ from outstanding sukuk in other parts of the world (Fong, 2013).

\section{Problem Statement and Significance of Study}

In view of the fact that from 1970s, there are numerous broad studies associated to issues that influence the corporate bond pricing, few experiential proofs on the issues affect the residential mortgage-backed securities (RMBS) price in nearly developed countries counting Malaysia. Malaysia is recognized as a main division of the bond market (2). In the UK, RMBS is established to be the major securitization division and a large amount of experiential proofs on the issues that influence pricing subject of RMBS has been reported. Despite the fact that Cagamas is the major factor for Residential and Commercial Mortgage-Backed Securities (CMBS), there are few studies on primary market spread determinants including Tranches, Credit Rating and Enhancement (3). Spreads are regularly connected with credit rating, loan to value and transaction size in developed countries. There are few studies which have focused on other factors beyond credit rating especially in non US Asset (2). According to them, issue of spread towards primary market is frequently unnoticed, mutually in previous study. In practice, with significant unsatisfactory regard to the fact that determinant has vital significance when searching to sketch the concluding assessment of issuing securitization Bakri et al (4), it has become an underlying research issue of this study. 


\section{Literature Review}

The term 'asset-backed securitization' (ABS) is employed in different ways by numerous researchers because the employment is not completely reliable. Asset-backed securitization is initially found in bank funding. Hess and Smith (1988), for instance, discuss asset-backed securitization in the background of financial intermediaries to administer interest rate revelation. The researchers described asset-backed securitization as a monetary intermediation procedure that re-bundles personal principal and interest payments of current loans to make novel securities (5).

More lately, the word asset-backed securitization is referred to structured finance, the broad procedure that illiquid assets go through the pooling, repackaging and sold to third-party stakeholders. So, asset-backed securitization can extremely be described as the procedure that assets are refinanced in the bazaar by mattering securities sold to capital stake-holders by a bankruptcyremote firm identified as special purpose vehicle (SPV). This explanation contains the basics of asset securitization.

There are numerous hypotheses that have been narrated to the securitization financing as it is illustrated that by securitizing a quantity of the corporation's assets could make monetary synergies, rooted in the trade-off hypothesis of assets arrangement replica. Furthermore, Ayotte and Gaon (6) demonstrate how ABS can decrease insolvency costs, for a number of issuing corporations. Asset securitization can subordinate companies' total charge of financing that is forecast by this replica. a researcher of ABS has mentioned previously that it is of value to mention that seizing one of the major advantages of securitization is that ABS illustrates issuance of extremely graded bonds, as shown by (7).

Similarly, it is evident that nonfinancial companies, gathered from firm's 10k disclosures, evaluated a quantity of forecasts employing great database of asset-backed securitizations (8). Their result approves the financial advantages in the form of inferior total financing costs throughout the employment of securitizations to a corporation, and improved investment returns to marketplace members. Moreover they seem to appreciate how these transactions influence the company's assets and credit danger, and consequently, this gap turn into the thrust of this research (9).

\section{Data and Methodology}

It is mentioned that the investigator might be permitted to inspect the dynamics of alter in short time series recurring remarks of cross sections by means of panel data investigation. Furthermore, it permits the investigator to have an immense flexibility regarding distinctions modeling and to arrest diverse performance across personal cross section.

Furthermore, it supplies additional flexibility, supplementary degree of freedom, and supplementary spread, fewer collinear between variables while employing panel data that will create competence in generate results. Furthermore, it enhanced the quantity and quality of information by considering different dimensions. The complex behavioral approaches can be catered through panel data investigation. Since panel data is connected to personal firms, eventually this leads to heterogeneity. The heterogeneity issue obviously has been considered by panel data approximation by allowing for personal precise variables.

In line with previous research in this area, using White(10) methodology would assist to determine the factor of influencing the primary market spread. We employ standard OLS regression estimation techniques and adjust for heteroscedasticity. The model estimated is:

$$
y=X \beta+u
$$

The data for this research has been taken from reliable and valid data which is from 2007 to 2012. This research is also using hypothesis testing to test relationship between the SPREAD with independent variables. The independent variables are year of issue, leverage, liquidity, loan to value, number of tranches, loan size and maturity Table 1 shows the hypotheses for this study:-

Table 1: Hypothesis

\begin{tabular}{|l|l|}
\hline $\mathrm{H}_{1}:$ & Loan to Value has significant effect with spread \\
\hline $\mathrm{H}_{2}:$ & Maturity has significant effect with spread \\
\hline $\mathrm{H}_{3}:$ & Loan Size has significant effect with spread \\
\hline $\mathrm{H}_{4}:$ & Number of Transaction has significant effect with spread \\
\hline $\mathrm{H}_{5}:$ & Liquidity has significant effect with spread \\
\hline $\mathrm{H}_{6}:$ & Leverage has significant effect with spread \\
\hline $\mathrm{H}_{7}:$ & Year of issue has significant effect with spread \\
\hline
\end{tabular}

Lastly, a cross sectional regression analysis is applied to show the relationship between dependent and independent variables at one period or point in time. The determinants of a spread are examined through cross-sectional regression analysis. The general crosssectional regression model as follows:-

Spreadi $=$ An $+\beta_{1}$ Loan To Value $+\beta_{2}$ Maturity $+\beta_{3}$ Loan Size + $\beta_{4} \#$ Tranches $+\beta_{5}$ Liquidity $+\beta_{6}$ Leverage +

$B_{7}$ Year of Issue $+E_{i t}(2)$

\subsection{Findings for Determinant of Primary Market Spread}

The cross section regression model is spelt out as follows:SPREAD $=0.1929472+-1.631196 \mathrm{LTV}+2.788655 \mathrm{MAT}+-$

0.0614173 LOAN_SIZE $+-0.0961168 \mathrm{TRN}+-$ 1.296305 LIQUID + - 0.1558607 LVG + 0.3781223 YR ISSUE $+\mathrm{e}_{\text {it }}(3)$

The primary market spread model which is F-value is 6.58 (Prob. $>\mathrm{F}=0.0002$ ). It means this model is significant and can be proceed while adjusted $\mathrm{R}^{2}$ stated $66 \%$ the model explaining the factor of this model.

Table 2: The Result for Primary Market Spread

\begin{tabular}{|c|c|c|c|}
\hline Variable & Coefficient & t-Statistic & Prob. \\
\hline C & 0.1929472 & 0.04 & 0.969 \\
\hline LTV & -1.631196 & -2.21 & $0.037 * * *$ \\
\hline MAT & 2.788655 & 1.80 & $0.085 * * *$ \\
\hline LOAN_SIZE & -0.0614173 & -0.24 & 0.809 \\
\hline TRN & -0.0961168 & -0.18 & 0.862 \\
\hline LIQUID & -1.296305 & -3.81 & $0.001 * * *$ \\
\hline LVG & -0.1558607 & -0.41 & 0.685 \\
\hline YR_ISSUE & 0.3781223 & 0.54 & 0.597 \\
\hline R-squared & 0.667 & F-statistic & 6.58 \\
\hline $\begin{array}{l}\begin{array}{l}\text { Adjusted } \\
\text { squared }\end{array} \\
\end{array}$ & 0.5656 & Prob(F-statistic) & 0.0002 \\
\hline $\begin{array}{l}\text { Sum squared } \\
\text { resid }\end{array}$ & 2.24362149 & & \\
\hline
\end{tabular}

$* * *$ Significant level of $1 \%$

The result shows that loan to value has significant level at $1 \%$ and negative relationship with primary market spread which it supports hypothesis 1 . Another variable that support hypothesis 2 which is maturity and it has significant at $1 \%$ level with primary market spread while it has positive relationship with the primary market spread. It also means the longer (shorter) the maturity the higher (lower) the spread.

The other variable such as loan size and transaction which is not significant and has negative relationship with primary market spread. This result reject both hypothesis loan size and transactions. The result shows that support hypothesis 5 where it has significant effect at $1 \%$ level with primary market spread. Other than that it shows Liquidity has negative relationship with primary market spread and it means the higher the liquidity the lower the spread. Similar finding of Merton(11) support the results of Leverage which has a negative relationship with primary market spread but the result does not support hypothesis 6 . The same result for Year of Issue which has a positive relationship with spread and does not support hypothesis 7 . 


\subsection{Findings for Revenue and Profits 2008-2012}

Table 3 provides the result from the sample data by using the financial report from RCE Marketing. The analysis is spelt out as follows:-

Table 3: Financial Performance 2008-2012 (RM ‘000)

\begin{tabular}{|l|l|l|l|l|l|}
\hline $\begin{array}{l}\text { Revenues and } \\
\text { Profits }\end{array}$ & $\mathbf{2 0 0 8}$ & $\mathbf{2 0 0 9}$ & $\mathbf{2 0 1 0}$ & $\mathbf{2 0 1 1}$ & $\mathbf{2 0 1 2}$ \\
\hline Revenue & $\begin{array}{l}131,93 \\
8\end{array}$ & $\begin{array}{l}215,40 \\
0\end{array}$ & $\begin{array}{l}255,61 \\
1\end{array}$ & 269,580 & $\begin{array}{l}229,85 \\
9\end{array}$ \\
\hline $\begin{array}{l}\text { Profit Before } \\
\text { Taxation }\end{array}$ & 66,761 & 92,335 & $\begin{array}{l}109,98 \\
9\end{array}$ & 140,099 & $\begin{array}{l}128,16 \\
5\end{array}$ \\
\hline Net Profit & 50,589 & 66,555 & 81,094 & 104,257 & $\begin{array}{l}101,35 \\
5\end{array}$ \\
\hline $\begin{array}{l}\text { Earnings per Share } \\
\text { (sen) }\end{array}$ & 7.83 & 9.37 & 10.72 & 13.33 & 12.95 \\
\hline
\end{tabular}

The revenue keep on increasing every year from 2008 to 2012 which ia increasing by $74.21 \%$ which comes from interest even though currently its drop from 2011 to 2012. The financial performance shows that profit before taxation also increasing by $91.9 \%$ whereby many government staff apply personal loan that makes income from interest rate increasing. Even though the subprime mortgage crisis happened in United States of America between 2008 to 2009 the net profit for RCE Marketing keep on growing by $31.56 \%$ and it shows that the company resilient during the crisis (12). Many big company in United States of America involved with Securitization collapse and some of the company has been bailed out by US government during subprime mortgage crisis (4). Earnings per share for this firm keep on increasing that shows that shareholders received more income with every share they hold.

\subsection{Findings for Revenue and Profits 2008-2012}

RCE Marketing has a good track record of on income statement and financial position for the past five years as shown on following Table 4

Table 4: Debt and Profitability Ratio

\begin{tabular}{|l|l|l|l|l|l|}
\hline & $\begin{array}{l}\mathbf{2 0 0} \\
\text { Type of Ratio }\end{array}$ & $\begin{array}{l}\mathbf{2 0 0} \\
\mathbf{9}\end{array}$ & $\begin{array}{l}\mathbf{2 0 1} \\
\mathbf{0}\end{array}$ & $\begin{array}{l}\mathbf{2 0 1} \\
\mathbf{1}\end{array}$ & $\begin{array}{l}\mathbf{2 0 1} \\
\mathbf{2}\end{array}$ \\
\hline Gearing Ratio (x) & 3.04 & 2.47 & 1.83 & 1.51 & 0.89 \\
\hline $\begin{array}{l}\text { Return on Average Shareholders' } \\
\text { Funds (\%) }\end{array}$ & $\begin{array}{l}\text { (4.3 } \\
7\end{array}$ & $\begin{array}{l}22.3 \\
2\end{array}$ & $\begin{array}{l}19.3 \\
6\end{array}$ & $\begin{array}{l}23.2 \\
5\end{array}$ & $\begin{array}{l}19.1 \\
5\end{array}$ \\
\hline Interest Coverage Ratio (Times) & 3.01 & 3.99 & 3.94 & 3.61 & 3.56 \\
\hline $\begin{array}{l}\text { Return on Average Total Assets } \\
\text { (\%) }\end{array}$ & 5.18 & 5.19 & 5.26 & 5.87 & 6.76 \\
\hline Dividend Per Share (sen) & 0.75 & 0.75 & 1.53 & 1.50 & 1.50 \\
\hline & 32.1 & 41.9 & 53.5 & 57.3 & 67.6 \\
Net Tangible Asset (sen) & 1 & 2 & 6 & 2 & 4 \\
\hline
\end{tabular}

From the table above shows that the firm would be able to reduce its debt more than $50 \%$ from 2008 to 2012. The firm also stated the firm would be able to pay interest. Return on investment though asset keep on increasing. Even though during subprime mortgage the firm would be able to pay high dividend. The value of the firm increasing $110 \%$ which mean the company value very strong every year since 2008. According to Rating Agency Malaysia the firm having very low default payment.

\section{Concluding Comments}

Overall, the result shows the model for this research is significance. Three variables which is loan to value, maturity and liquidity which is significant to contributing to determinant primary market spread which 3 out 7 hypothesis supported the results. Financial performance during 5 year from 2008 to 2012 of this firm shows that profit keep on increasing means that the firm reaping the fruit of investment handsomely and investor getting higher earning every share they hold. The debt of this firm reducing every year. The shareholder getting return in term of dividend for every share they hold. Other than that the firm value keep on increasing based on increasing value in net tangible asset since 2008 to 2012 .

There is a limitation on this model because so many factor could be included in this model by including external factor such as Gross Domestic Product, Overnight Policy Rate and Exchange Rate and other internal factor that would make the model more robust and acceptable. Contribution for this paper which is empirical result for government staff personal loan securitization.

\section{Acknowledgement}

This research and conference in Johor, Malaysia was supported and funding by Research Acculturation Grant Scheme (RAGS) [File No: RAGS/1/2015/SS01/FPTT/02] Ministry of Higher Education and Universiti Teknikal Malaysia Melaka.

\section{References}

[1] Sahiq ANM, Rahman NHA, Ismail S, Bakri MH, Husin A, Ali R. A Conceptual Study on the Role of Waqf in Developing Successful Young Entrepreneurs. Advanced Science Letters. 2016;22(12):4477-80.

[2] Fabozzi FJ, Vink D. Determinants of primary market spreads on UK residential mortgage-backed securities and the implications for investor reliance on credit ratings. The Journal of Fixed Income. 2012;21(3):7-14

[3] Vink D, Thibeault AE. An empirical analysis of asset-backed securitization. 2008.

[4] Bakri M, Ali R, Ismail S. The Study of Residential Mortgage Backed Securities During Subprime Mortgage: Malaysian Experience. Advanced Science Letters. 2015;21(5):1468-72.

[5] Idris NH, Yazid ZA, Faique FA, Daud S, Ismail S, Bakri MH, et al. Financial Literacy and Debt Burden Among Malay Youth Workers in Malaysia. Advanced Science Letters. 2016;22(12):4288-92.

[6] Ayotte K, Gaon S. Asset-backed securities: costs and benefits of bankruptcy remoteness. 2005

[7] Ali R, Ismail S, Bakri M. Proposed Islamic Educational Loanbacked Securities for Quality Life of University Graduates in Malaysia. Procedia-Social and Behavioral Sciences. 2015;201:8592.

[8] Rahman A, Hayati N, Sahiq M, Nadiah A, Ismail S, Bakri MH, et al. Antecedents of a successful business venture for young entrepreneurs. Advanced Science Letters. 2016;22(12):4485-8.

[9] Ismail S, Faique FA, Bakri MH, Zain ZM, Idris NH, Yazid ZA, et al. The Role of Financial Self-Efficacy Scale in Predicting Financial Behavior. Advanced Science Letters. 2017;23(5):4635-9.

[10] White H. A heteroskedasticity-consistent covariance matrix estimator and a direct test for heteroskedasticity. Econometrica: Journal of the Econometric Society. 1980:817-38.

[11] Merton RC. On the pricing of corporate debt: The risk structure of interest rates. The Journal of finance. 1974;29(2):449-70.

[12] Bakri MH, Dabas N, Ismail S, Hamid BA. Islamic Student Financing Back Securitization in Malaysia. Advanced Science Letters. 2017;23(9):8090-3. 